\begin{tabular}{|l|l|l||}
\hline \multicolumn{2}{|c|}{ PublisherInfo } \\
\hline \hline PublisherName & $:$ & BioMed Central \\
\hline \hline PublisherLocation & $:$ & London \\
\hline \hline PublisherImprintName & $:$ & BioMed Central \\
\hline \hline
\end{tabular}

\title{
Angiotensin and angiogenesis
}

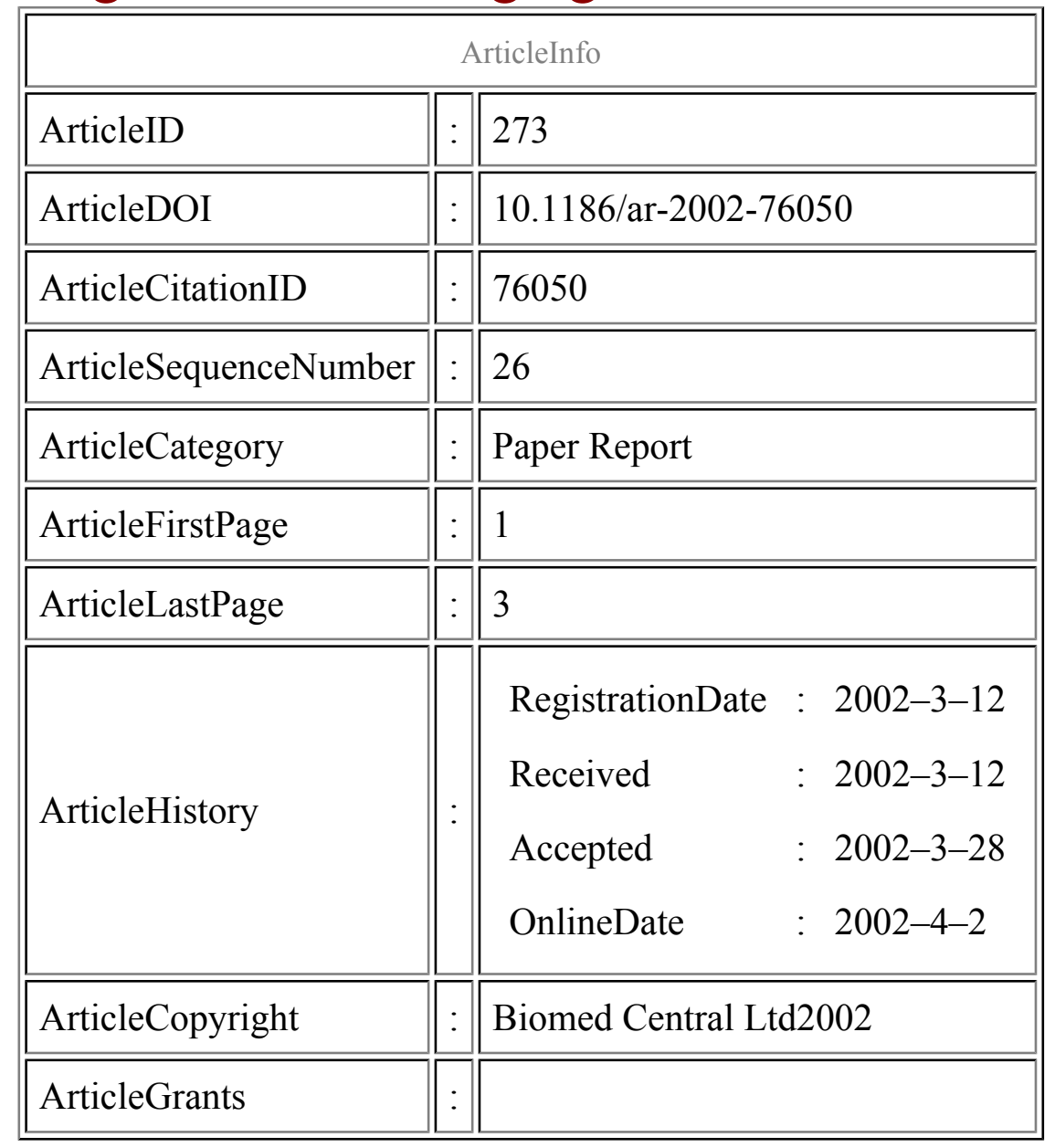




\begin{tabular}{|l|l|l||}
\hline ArticleContext & $:$ & 130754411 \\
\hline
\end{tabular}

Jose L Pablos, ${ }^{\text {Aff1 }}$

Affl Hospital 12 de Octubre, Madrid, Spain

\section{Keywords}

angiogenesis, angiotensin II, inflammation, VEGF

\section{Context}

Angiogenesis is a common response that participates in the pathogenesis of a variety of chronic diseases such as cancer and chronic inflammation. In chronically inflamed tissues, angiogenesis seems to be a perpetuating mechanism that allows the recruitment of inflammatory cells and thereby contributes to the perpetuation of chronic inflammation. Therefore, the molecular mechanisms that induce angiogenesis are potential targets for anti-inflammatory therapies. The authors studied the participation of the renin-angiotensin system (RAS) in angiogenesis.

\section{Significant findings}

In response to hindlimb ischemia, microvascular and collateral vessel formation were reduced in angiotensin II (ATII) type 1a (AT1) receptor knockout mice $\left(\mathrm{AT}^{-\mathrm{a}^{-/}}\right)$as compared to wild-type (WT) mice . Ischemia-induced angiogenesis was also impaired in WT mice treated with an AT1 receptor blocker at supratherapeutic doses. Infiltrating macrophages and $\mathrm{T}$ lymphocytes expressed VEGF in ischemic tissue, and the expression of VEGF and monocyte chemoattractant protein-1 (MCP-1) was decreased in $\mathrm{AT}_{1 \mathrm{a}^{-/-}}$mice, together with reduced infiltration by macrophages and Tlymphocytes. AT1 $\mathrm{a}^{-}$ ${ }^{1-}$ mice showed decreased leukocyte infiltration in the glycogen-induced peritonitis model. Impaired angiogenesis in $\mathrm{AT}_{1} \mathrm{a}^{-/-}$mice was rescued by intramuscular transplantation of mononuclear cells (MNCs) obtained from WT mice.

\section{Comments}


The results of this study underline the role of $\mathrm{MNC}$ infiltration in the angiogenic response to ischemia and suggest that the AT1 receptor regulates such infiltration. The authors suggest that in AT1 $\mathrm{a}^{-/-}$mice, inflammatory cell recruitment is not only impaired in response to ischemia but also to less specific stimuli. They observed a modest decrease in leukocyte infiltration, presumably neutrophils, during the acute response to intraperitoneal glycogen. The proinflammatory effects of the RAS and its participation in vascular and renal inflammatory responses have been extensively supported by experimental studies. However, it is still unclear whether the RAS participates in other inflammatory models and whether pharmacological interventions can reproduce the effects of genetic deletion of AT1 receptors on either inflammation or angiogenesis.

\section{Methods}

Surgical excision of femoral artery, laser Doppler, angiography, histology, immunofluorescence staining, western blotting

\section{References}

1. Sasaki Ki K, Murohara T, Ikeda H, Sugaya T, Shimada T, Shintani S, Imaizumi T: Evidence for the importance of angiotensin II type 1 receptor in ischemia-induced angiogenesis. J Clin Invest. 2002, 109: 603-611. 